\title{
Composition of macrobenthos from the Central Indian Ocean Basin
}

\author{
S Pavithran, B S Ingole*, M Nanajkar, C Raghukumar, \\ B N NATH and A B VAlsangkAR \\ National Institute of Oceanography (CSIR), Dona Paula, Goa 403 004, India. \\ *e-mail: baban@nio.org
}

The deep sea is well known for its high faunal diversity. But the current interest in its abundant polymetallic nodules, poses a threat to the little known benthic organisms surviving in this unique environment. The present study is the first attempt to document the Indian Ocean abyssal benthic diversity of macroinvertebrates and to investigate its relation to the surface primary production (chl-a), sediment labile organic matter, organic carbon and texture. The present study is based on 87 individuals. Altogether 39 macroinvertebrate genera were obtained from water depths of 4500-5500 m from 23 box cores. Reduction in macrobenthic density was seen towards the southern latitudes. The area was dominated by deposit feeding macrobenthos. Vertically, the fauna was distributed down to $30 \mathrm{~cm}$ depth, with the highest faunal density in the top $2-5 \mathrm{~cm}$ sediment section. The values for population density were strongly correlated with surface water chl- $a$ and sediment protein, indicating supply of fresh organic matter as a critical factor for maintaining the deep sea benthic diversity and abundance.

\section{Introduction}

Although the deep sea is one of the most remote and least known environments, it has not been spared from human interference. Due to depleting resources, mankind is looking towards the ocean as an alternative source of hitherto land-based minerals. The deep sea is also known to have large deposits of sulphides, polymetallic nodules and gas hydrates. There are discussions on a global level for commercial mining of these resources in future, which implies a tremendous threat to the deep sea organisms, some even new or little known to science. The Central Indian Ocean Basin (CIOB) is covered with dense polymetallic nodules and is considered to have a high quality of commercial grade nodules (Prasad 2007). However, of the three oceans, the Indian Ocean is the least studied in terms of deep sea fauna.

Benthic organisms play an important role as food for large carnivores and some sediment-dwelling forms influence the mixing of organic and inorganic matter in the upper sediments through bioturbation. Macrobenthos is also known to control the concentration and accretion of metals in the deep sea, helping indirectly in the nodule growth (Riemann 1983).

Only $1-3 \%$ of the surface production is known to be available to these deep sea organisms as food. In the deep sea environment, specialist carnivores become increasingly scarce with depth, presumably because of the decreasing food supply (Gage and Tyler 1991). The small size of many deep sea species may allow them to select individual particles (Jumars and Penry 1989). Macrobenthos density and biomass in the deep sea are related to the carbon deposition flux, whereas, meiofaunal assemblages are more linked to the local bacterial production and sediment characteristics (Vanreusel et al 1995; Flach et al 2002). In deepsea sediments bacteria are suggested to represent an important storage of living and readily

Keywords. Abyssal; macrobenthos; diversity; latitudinal distribution; Central Indian Ocean. 


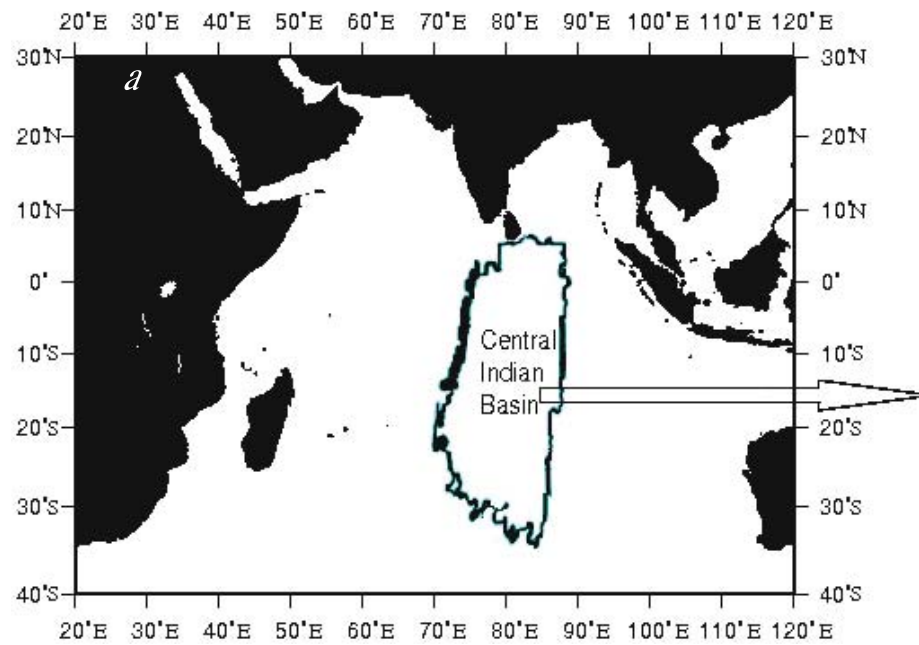

(a)

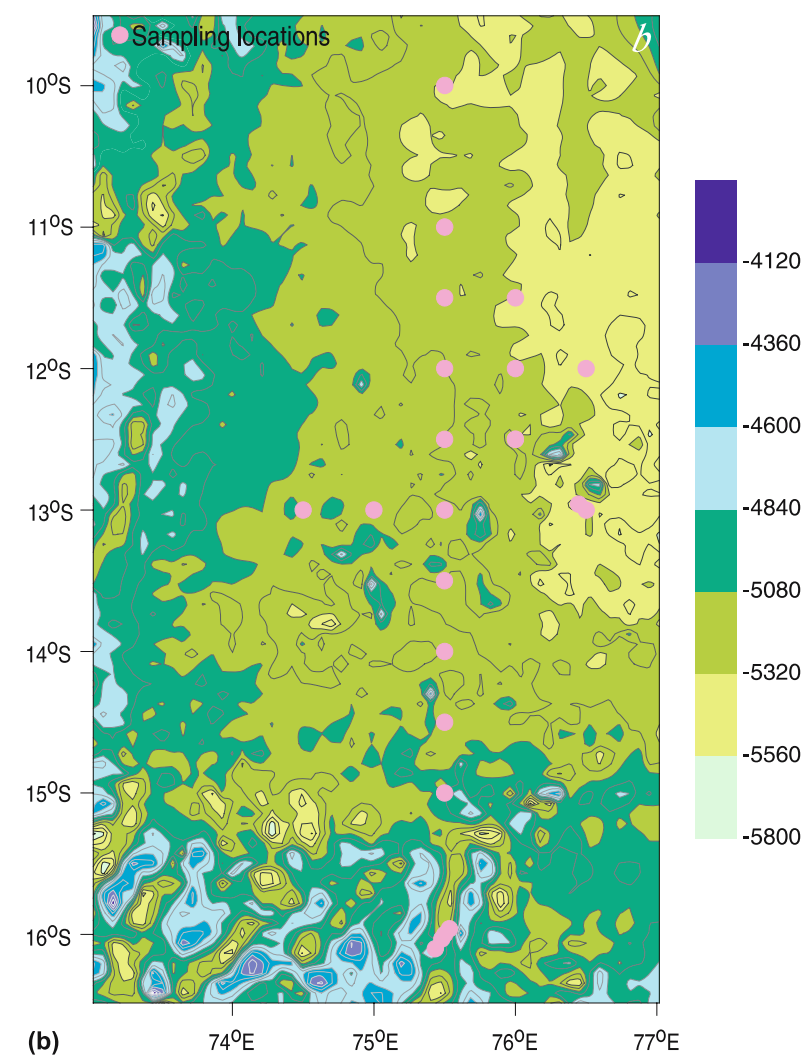

(b)

Figure 1. (a) CIOB and (b) depth contours (meters) and box core locations in the CIOB.

available organic carbon (Danovaro et al 1995), and might represent a major trophic link to the meiofauna.

All impact studies need a sound basis against which impacts originating from experiments or commercial actions may be assessed. The present study was aimed at providing baseline data on the density, diversity and distribution of macrobenthos in the Indian Ocean. Earlier studies on macrobenthos in the Indian Ocean were largely confined to group level identification (Ingole et al 2005 and references therein). Recently, Pavithran et al (2007) studied these organisms up to family/genus level. However, the macrobenthic diversity was related only to organic carbon. The current investigation provides the faunal data up to family/genus/species level and their relation with the biogeochemical parameters. The documentation of the deep-sea biodiversity will be useful in understanding the global species distribution and their role in different ecological habitats. In addition, inventorization of macrobenthos can be used as reference information for biodiversity conservation of the less known abyssal fauna of the Indian Ocean. However, owing to the comparatively small sample size - a problem frequently faced in deepsea studies, the results of the current study should be treated with caution.

\section{Materials and methods}

\subsection{Sampling and analysis}

Twenty three box cores were sampled onboard R.V. Akademic Boris Petrov in April 2005 from the Central Indian Ocean Basin (CIOB: figure 1a), sampling depths ranging between 4500 to $5500 \mathrm{~m}$ (figure $1 \mathrm{~b}$ ) between latitudes $10^{\circ}-16.1^{\circ} \mathrm{S}$ and longitudes $74.5^{\circ}-76.5^{\circ} \mathrm{E}$. Sediment samples were collected with a $0.25 \mathrm{~m}^{-2}$ spade box corer $(50 \times 50 \times 50 \mathrm{~cm}$ size $)$. The subsamples for macrobenthos were taken with the help of a PVC core tube $(12 \mathrm{~cm}$ dia. $50 \mathrm{~cm}$ length from each box core) and quadrant $(15 \times 15 \times 10 \mathrm{~cm}, 3$ subsamples for each box core). The PVC core samples were subsectioned at $0-2,2-5,5-10,10-15,15-20 \mathrm{~cm}$ depth through the complete core length. Sub-sectioning of the core sample was done with the help of a locally developed core cutter. All the sub-samples were preserved in neutralized $5 \%$ formalin-Rose bengal solution prepared in filtered sea water. These samples were later sieved using $0.5 \mathrm{~mm}$ stainless steel sieves and the organisms retained on the sieves were collected and sorted groupwise.

Surface water chl- $a$ data was extracted in individual locations in February-March 2005 from the Sea-viewing Wide Field-of-view Sensor (SeaWifs-weekly data), considering that the 


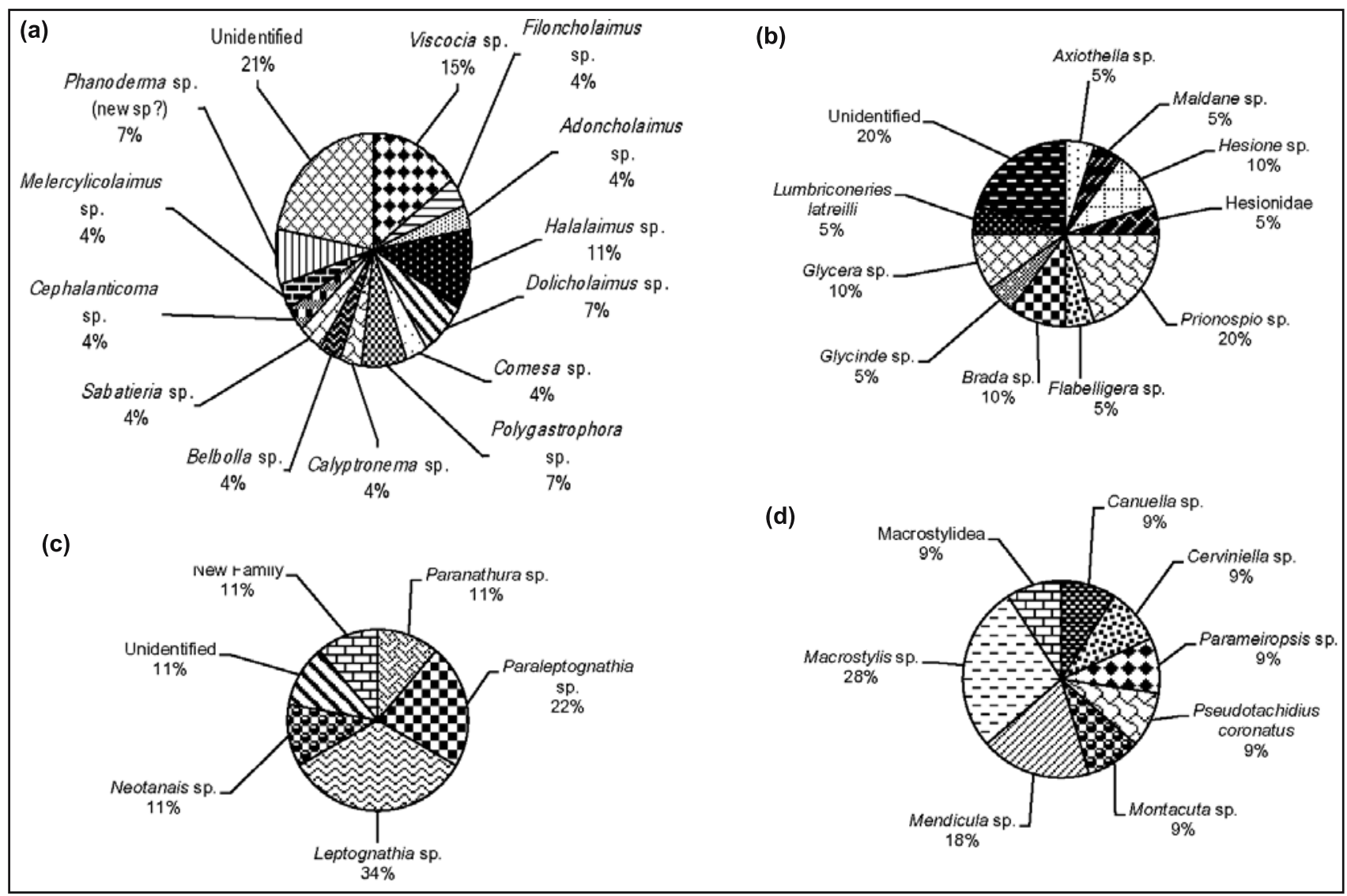

Figure 2. Composition of macrobenthos (a) Nematodes, (b) Polychaetes, (c) Tanaids, and (d) other dominant groups.

surface particles will take, on an average, 40-48 days to reach the seabed (Lampitt and Antia 1997). Sediment organic carbon estimation was carried out using wet oxidation method (El Wakeel and Riley 1957). For the estimation of sediment protein and carbohydrate, air-dried sediment samples were homogenized using a mortar and pestle. Protein estimation was carried out using the Folins-phenol method (Lowry et al 1951) using Bovine serum albumin as the standard. Carbohydrates were estimated by phenol-sulphuric acid method using glucose as the standard (Kochert 1978). For sedimentological studies, the sand content was determined after wet sieving through a $63 \mu \mathrm{m}$ sieve. The silt $(63-20 \mu \mathrm{m})$ and clay $(<20 \mu \mathrm{m})$ contents were determined following the standard pipette analysis method (Folk 1968).

\subsection{Data analysis}

Subsequently, all the macrobenthic specimens were identified to the lowest possible level under a stereoscopic microscope. All unidentified specimens are referred to by their generic/family names and were considered in single taxonomic category.

All data were subjected to Shapiro-Wilks test to check for normality. All environmental parameters were subjected to factor analysis. Spearman's coefficient was used to detect significant correlations between parameters.

\section{Results}

\subsection{Faunal composition and abundance}

The data presented in this study is based on 87 individuals collected from 23 box cores. The low abundance probably resulted from the sampling artifact, where 69 quadrants $(15 \times 15 \times 10 \mathrm{~cm})$ were sub-sampled. A total of seven macrobenthic groups were obtained from the 23 deep-sea sediment samples. Large sized $(>0.5 \mathrm{~mm})$ nematodes were the most diverse group with 14 species (figure 2a). It was followed by polychaetes with 11 species (figure $2 \mathrm{~b}$ ). Crustacea was represented by 12 species, of which Tanaidacea had six species (figure 2c), Harpacticoida had four species and Isopoda had two species (figure 2d). Mollusca were represented by two species, both belonging to the order Veneroida (bivalves; figure 2d). In terms of composition, Nematoda constituted $40 \%$ of the total fauna followed by Polychaeta $(29 \%)$, Tanaidacea $(13 \%)$, Isopoda $(6 \%)$, Harpacticoida (6\%), Veneroida (4\%) and Nemertina (1.5\%). 
Table 1. Composition (\%) of polychaetes and nematodes based on their feeding pattern.

\begin{tabular}{llc}
\hline Taxa & \multicolumn{1}{c}{ Feeding type } & $\%$ \\
\hline Polychaetes & Surface deposit feeders & 70 \\
& Subsurface deposit feeders & 13.33 \\
& Carnivores & 16.66 \\
Nematodes & Predatory omnivores & 61.54 \\
& Selective deposit feeders & 19.23 \\
& Non-selective deposit feeders & 7.69 \\
& Epigrowth feeders & 11.54 \\
\hline
\end{tabular}

Among the identified nematodes, Viscosia sp. $(15 \%)$ was the most dominant, while the polycheate community was dominated by Prionospio sp. (20\%). Among tanaids, Leptognathia sp. constituted $34 \%$ to the tanaidacea community, followed by Paraleptognathia sp. (22\%). Other dominant macrobenthos comprised of harpacticoids, bivalves and isopods. Similar to the nematodes, a substantial number of large sized harpacticoids were encountered on the $0.5 \mathrm{~mm}$ mesh sieve. A total of four harpacticoid species were obtained viz., Canuella sp., Cerviniella sp., Parameiropsis sp., Pseudotachidius coronatus each contributed $9 \%$ to the macrobenthic community. Between the two species of Veneroida, Mendicula sp. (18\%) was the dominant one followed by Montacuta sp. (9\%). Macrostylis sp. (28\%), was the dominant Isopoda, while the contribution by an unidentified isopod species (family Macrostylidae) was $9 \%$. The total density of macrobenthos ranged between zero and 133 ind $\cdot \mathrm{m}^{-2}$, with a mean density of $44 \pm 43 \mathrm{sd}$ ind $\cdot \mathrm{m}^{-2}, \mathrm{n}=23$. The polychaete community in CIOB was dominated by deposit feeding polychaetes $(68.8 \%)$, carnivores $(18.8 \%)$ and subsurface deposit feeders (12.5\%; table 1). Only two carnivore species were obtained in the present study viz., Glycera sp. and Glycinde sp. Nematodes belonging to four different feeding types were obtained $(62 \%$ were predatory omnivores, $14 \%$ selective deposit feeders, $14 \%$ epigrowth feeders and $10 \%$ non-selective deposit feeders) in the current study. The dominance of deposit feeders over carnivore macrobenthos means that organic matter is the main food for the macrobenthic community in the CIOB. However, very little is known about the trophic roles of other deep-sea macrobenthos, hence feeding type categorization was limited to polychaetes and nematodes.

\subsection{Relationship between macrobenthic density and sedimentary environment parameters}

Although there was high variability among stations, the macrobenthic density appeared to be positively correlated with organic carbon $(\mathrm{p}=0.002$; figure $3 \mathrm{a})$, sediment protein $(\mathrm{p}=0.05$; figure $3 \mathrm{~b})$ and chl- $a(\mathrm{p}=0.02$; figure $3 \mathrm{c})$. It appears that, the macrobenthic density augments with increase in these parameters. In contrast a significant negative trend of macrobenthos $(\mathrm{p}=0.009$; figure $3 \mathrm{~d})$, organic carbon $(\mathrm{p}=0.01$; figure $3 \mathrm{e})$ and chl- $a(\mathrm{p}=0.002$; figure $3 \mathrm{f})$ was observed with increasing latitude in the southern hemisphere. It suggests a decreasing trend of these parameters with increasing latitude southwards.

Significant positive correlation was observed between chl- $a$ and organic carbon $(\mathrm{p}<0.05$; figure 4). Hence, an increase in chl- $a$ enhances the sediment organic carbon and labile organic matter content in the seabed. However, sediment carbohydrate did not show a significant correlation with chl-a. Silt-clay-sand (\%) did not show any correlation with macrobenthic density, sediment organic carbon, sediment protein and carbohydrate.

Unrotated factor analysis reduced the seven sediment and biological variables to three factors with eigene values greater than 1.0 (table 2). Factor loadings express the relative contributions of original variables to the derived factors. Using a correlation (loading) of 0.7 or greater to indicate a strong contribution to a factor, it is evident that factor 1 was mostly influenced by chl- $a$ and organic carbon (figure 5). Factor 1 explained $39 \%$ of the total variance of the original measures. Factor 2 explained $31 \%$ of the total variance and was influenced mainly by clay, silt and sand. Factor 3 contained $15 \%$ of the total variance and was influenced by sediment protein and CHO. Factor 1 through 3 accounted for $85 \%$ of the total variance explained by these factors.

\subsection{Vertical distribution of macrobenthos}

Vertically, fauna was observed down to $30 \mathrm{~cm}$ sediment depth (figures 6 and 7a). Highest density was observed at the sediment depth of $2-5 \mathrm{~cm}$ $\left(21\right.$ ind $\cdot \mathrm{m}^{-2}$ ) whereas the top $0-2 \mathrm{~cm}$ had lower density $\left(11 \mathrm{ind} \cdot \mathrm{m}^{-2}\right.$; figure 6$)$. Generally, the higher species diversity was in the $2-5 \mathrm{~cm}$ sediment section with six species, while the top 0-2 cm had only two species and $5-10 \mathrm{~cm}$ section had only four species. The lower $10-30 \mathrm{~cm}$ section showed the presence of six species (figure 6). Capitella minima and Odanticoma sp. were present at greater $(15-20 \mathrm{~cm})$ sediment depth.

Sediment organic carbon showed decreasing trends with increasing sediment depth (figure $7 \mathrm{~b}$ ). A similar trend was also observed for sediment protein and carbohydrate. Overall, the top $2 \mathrm{~cm}$ sediment section had higher protein value $\left(1.0 \mathrm{mg} \mathrm{g}^{-1}\right.$ dry wt), and below $2-10 \mathrm{~cm}$ the values were low (figure 7c). Similar results were observed for $\mathrm{CHO}$ 

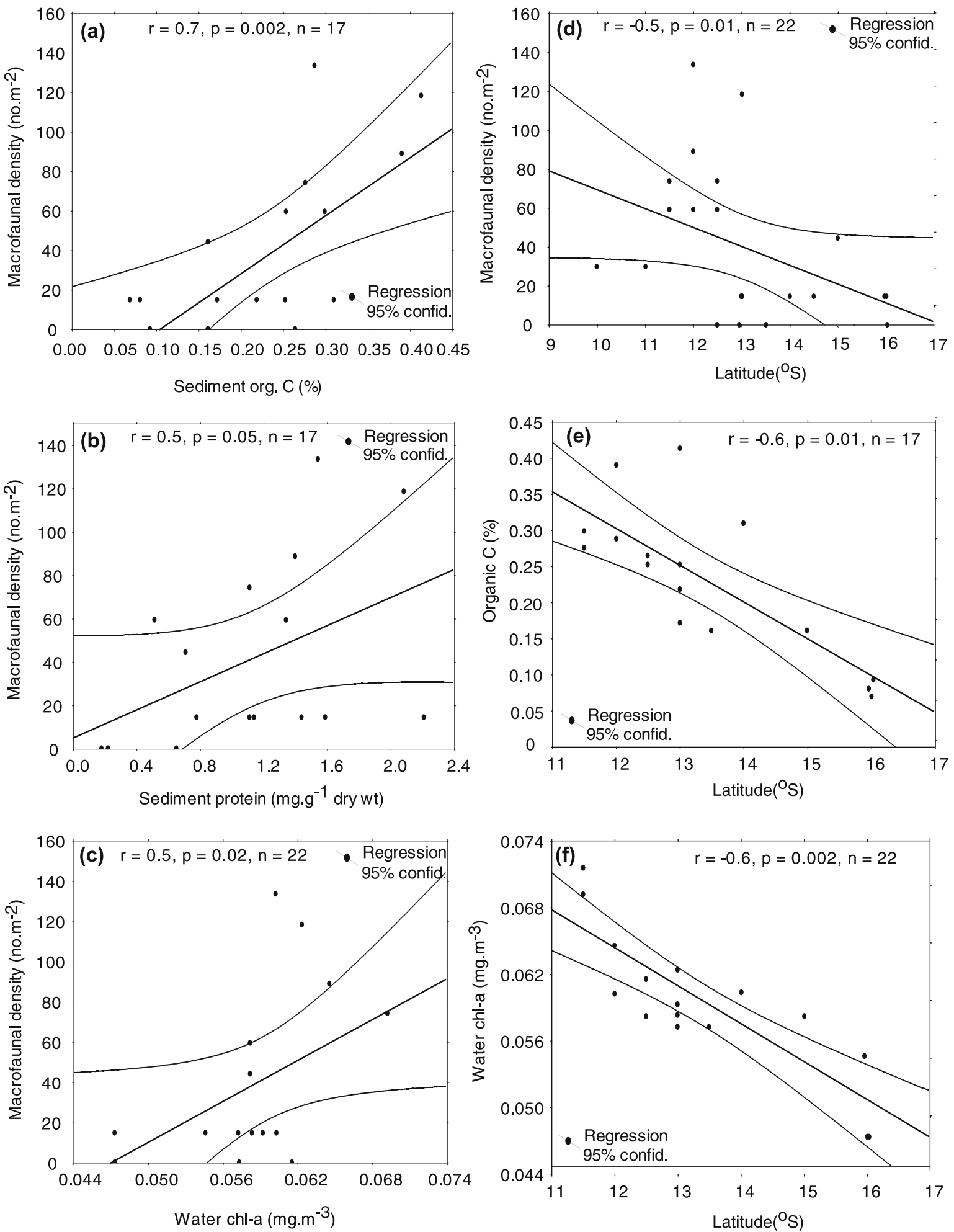

Figure 3. Relationship of macrobenthos and latitude with sediment organic carbon, protein and water chl- $a$.

with higher values in the top $0-2 \mathrm{~cm}\left(0.41 \mathrm{mg} \mathrm{g}^{-1}\right.$ dry wt) and low $\mathrm{CHO}$ concentrations in $2-10 \mathrm{~cm}$ sediment depth (figure 7c). Macrobenthic density showed a significant correlation with sediment protein $(\mathrm{r}=0.8, \mathrm{p}=0.03, \mathrm{n}=7)$ and carbohydrate $(\mathrm{r}=0.8, \mathrm{p}=0.02, \mathrm{n}=7)$ through sediment depth.

\section{Discussion}

4.1 Faunal composition and abundance

As in most of the benthic sedimentary habitats, the faunal composition was dominated by the 


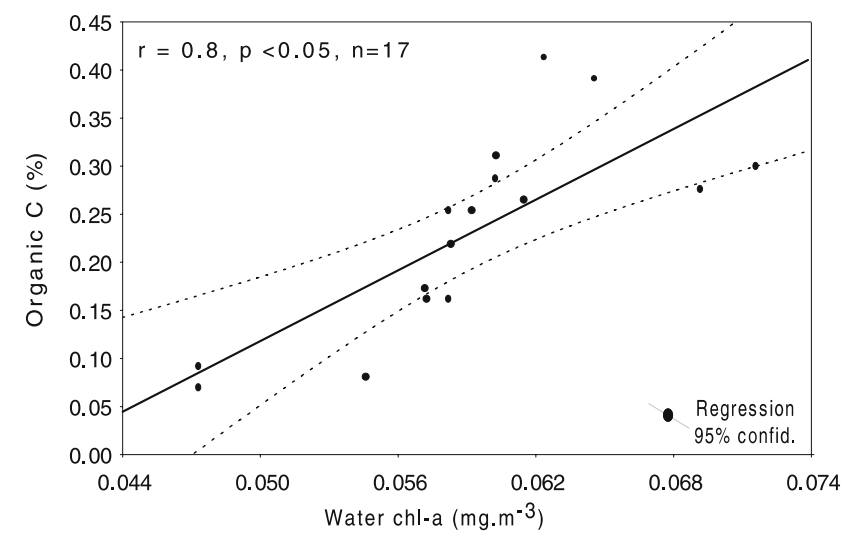

Figure 4. Relationship between water chl- $a$ and sediment organic carbon.

Table 2. Eigene values for the seven environmental variables studied in the CIOB.

\begin{tabular}{lcccc}
\hline Factors & $\begin{array}{c}\text { Eigen } \\
\text { value }\end{array}$ & $\begin{array}{c}\% \text { total } \\
\text { variance }\end{array}$ & $\begin{array}{c}\text { Cumulative } \\
\text { eigen value }\end{array}$ & $\begin{array}{c}\text { Cumulative } \\
\%\end{array}$ \\
\hline 1 & 2.71 & 38.76 & 2.71 & 38.76 \\
2 & 2.20 & 31.38 & 4.91 & 70.14 \\
3 & 1.03 & 14.66 & 5.94 & 84.80 \\
\hline
\end{tabular}

nematodes and polychaetes with mean density of 44 ind $\cdot \mathrm{m}^{-2}$. The low density in the abyssal CIOB was probably due to the lower primary productivity (PP) in the surface waters. According to Matondkar et al (2005) the surface water PP values in CIOB ranged between $9.06 \mathrm{mg} \mathrm{C} \mathrm{m}^{-2} \mathrm{~d}^{-1}$ and $103.4 \mathrm{mg} \mathrm{C} \mathrm{m}^{-2} \mathrm{~d}^{-1}$, which is considerably lower than in the other oceans (table 3). Similarly, organic carbon values seem to be the lowest in Central Indian Ocean in comparison with other known deep-sea areas. The low organic content in the CIOB ( 0.07 to $0.41 \%$ in the present study) is attributed to low sediment accumulation rates (Pattan et al 2005) that allow more remineralization at the sediment water interface. However, comparisons between different deep-sea macrobenthic studies poses a problem due to the varying sieve sizes used (table 3). Kröncke et al (2003) used a sieve size similar to that of the present study and reported a very low density ( 15 ind $\cdot 0.25 \mathrm{~m}^{-2}$ ) of macrobenthos in the deeper stations in the eastern Mediterranean. These values were comparable with those of other studies from Indian Ocean (Ingole et al 1992; Pavithran et al 2007). In contrast, work carried out by Sibuet et al (1989) using a sieve size of $0.25 \mathrm{~mm}$ reported a very high density of macrobenthos $\left(95-2159 \mathrm{ind} \cdot \mathrm{m}^{-2}\right)$ from the Atlantic Ocean. Comparatively in studies by Glover et al (2002) in the Pacific Ocean with a sieve size of $0.3 \mathrm{~mm}$, the polychaete density, which is the dominant macrofauna group, ranged between 9 and 84 ind $\cdot 0.25 \mathrm{~m}^{-2}$. Though the macrofaunal density

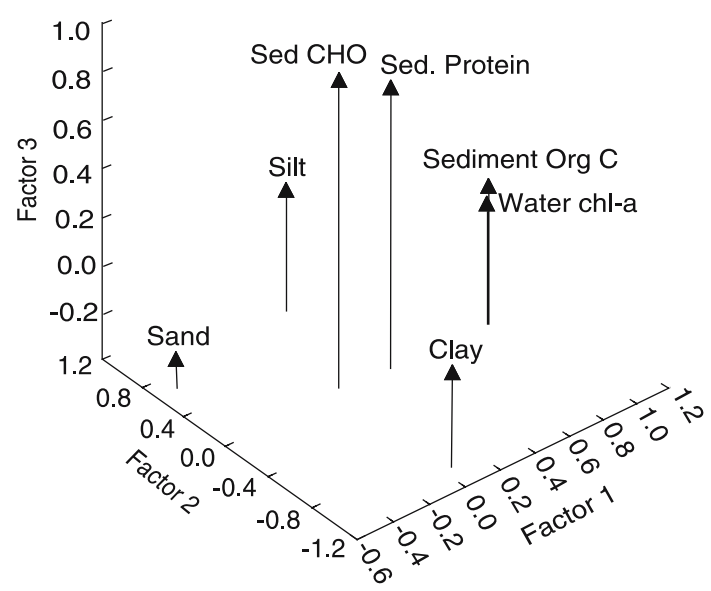

Figure 5. Factor analysis of water and sediment parameters.

in the CIOB is very low compared to the abovementioned studies it can be attributed to the difference in sieve sizes. However, all the studies point towards the fact that macrobenthic abundance is related to the overhead production (table 3 ). Hence the possibility of low abundance of macrobenthos in the CIOB can be due to a combination of the above discussed factors.

Deep-sea macrobenthos are known to be filter feeders, deposit feeders or predator/scavenger (predating, e.g., on meiofauna), but the majority of them are known to be deposit feeders. The feeding type of the dominant groups, nematodes and polychaetes suggests that the area is dominated by deposit feeders.

Among the polychaetes, Prionospio sp. was the most dominant, because they are opportunistic deposit feeders (Fauchald and Jumars 1979; Santosa et al 2009). On morphological grounds, it is postulated that the carnivorous habit is the primary feeding mode among the Glycera sp., and that an unknown, probably small number of species have become detritivores. It is further suggested that, bathyal and abyssal glycerids can use both modes (Fauchald and Jumars 1979) and hence could adapt to the less productive CIOB for their survival.

In the present study, the feeding type categorization of nematode is based on the basis of shallow water feeding strategies described by Wieser (1953) and Tietjen and Lee (1977). The most dominant predatory omnivores were Viscosia sp., Polygastrophora sp. and Dolicholaimus sp., followed by Filoncholaimus sp., Adoncholaimus sp., Calyptronema sp., Belbolla sp., Metacylicolaimus sp. and Trileptium sp., Leptosomatum sp. and Halalaimus sp. were the most dominant selective deposit feeders. Cephalanticoma sp. and Sabatieria sp. were the non-selective deposit feeders, while Comesa sp. and Phanoderma sp. were 


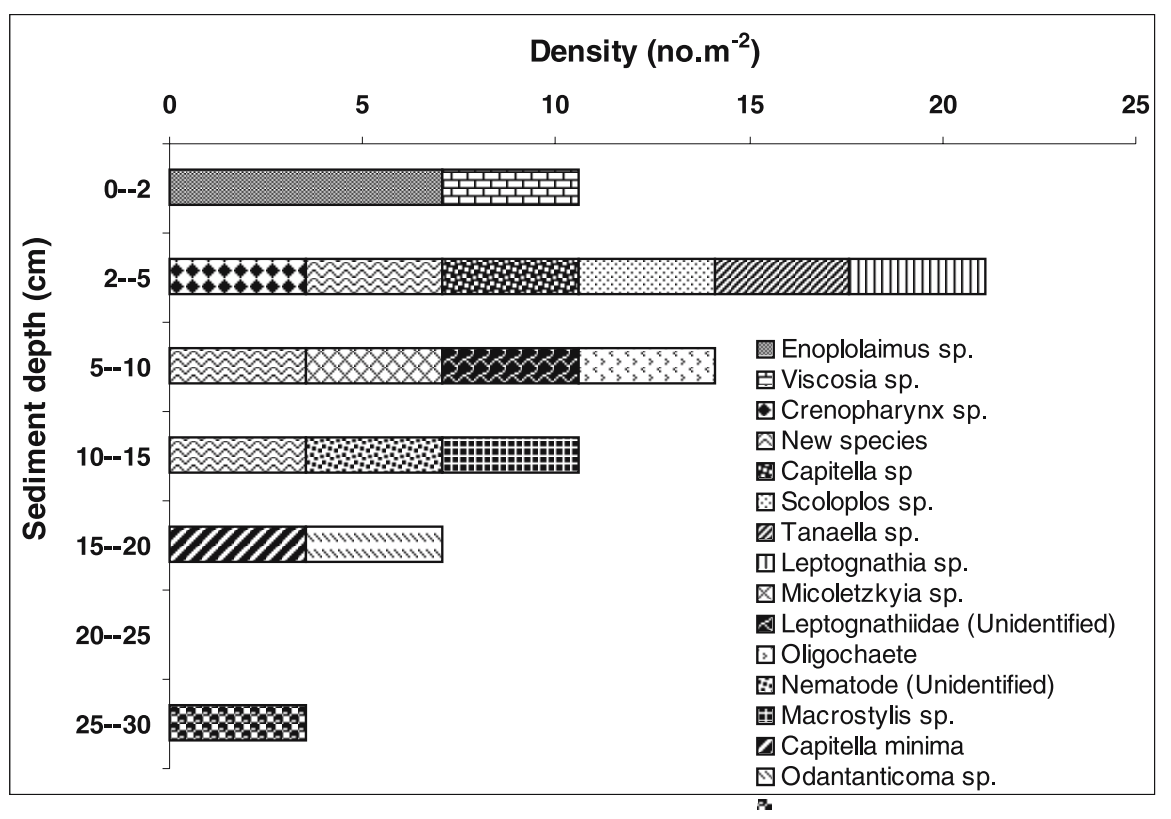

Figure 6. Vertical distribution of macrobenthos in the sediment.
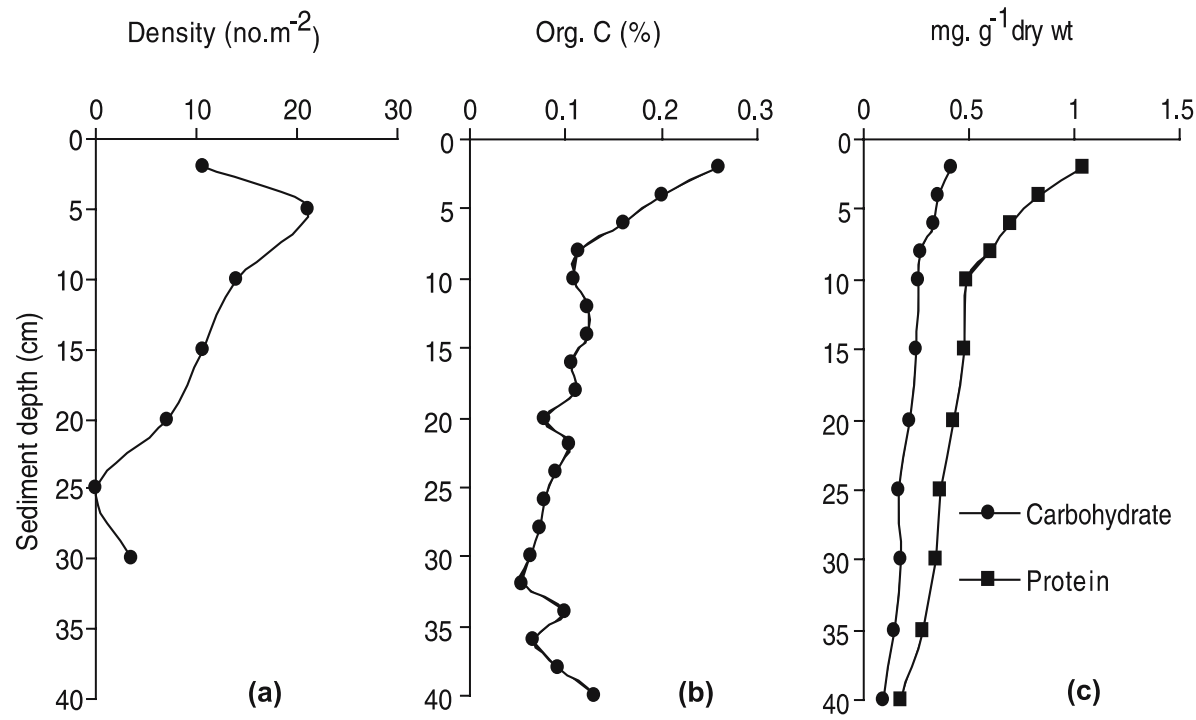

Figure 7. Vertical distribution of (a) macrobenthos density, (b) sediment organic carbon and (c) sediment protein and carbohydrate.

the epigrowth feeders. However, the predator-prey encounter in the deep sea would be much less than that of the coastal environment; hence, the feeding strategy might vary in the deep sea. It would also depend on the strike rate of the predator and their success as predators in the deep sea (Moens et al 1999).

According to various benthic studies, the structure of the macrobenthos depends on the feeding modes of the species present, which in turn depend on the quality of available food (Dauwe et al 1998; Wieking 2002; Kröncke et al 2003). Fresh organic matter will result in abundance of species mainly feeding at the sediment surface or in the benthic boundary layer, while subsurface deposit-feeders and endobenthic predators have been found to be related to total organic carbon levels (Gaston 1987; Maurer et al 1994; Dauwe et al 1998) or to sediments with more refractory material (Flach and Heip 1996; Gutiérrez et al 2000; Kröncke et al 2003).

In the present study, the sedimentary proteins (mean: $1.0 \mathrm{mg} \cdot \mathrm{g}^{-1}$ ) were higher than the carbohydrates $\left(0.4 \mathrm{mg} \cdot \mathrm{g}^{-1}\right)$. Higher protein to carbohydrate ratio indicates the presence of fresh flux (Danovaro et al 1993) and appears to be the most 


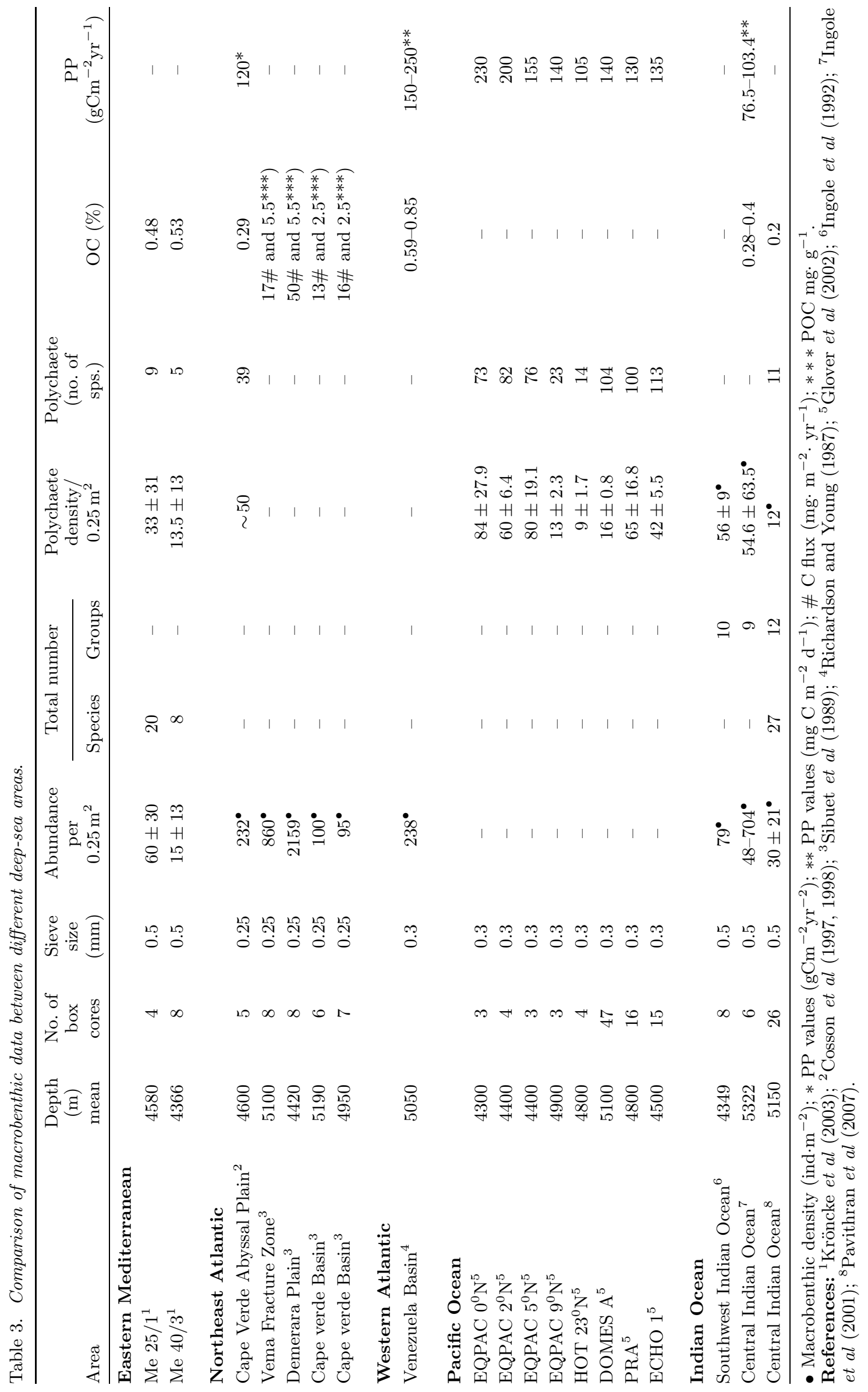


probable reason for the relative abundance of surface deposit feeding fauna in the CIOB and lower ratio indicates the presence of aged organic matter (Danovaro et al 1993). Thus, availability of sedimentary proteins is an important factor regulating the abundance of deep sea benthic consumers. The labile part of the organic matter consists of the major fraction of carbohydrates and proteins, which are assumed to be easier to digest and assimilate by the benthic consumers, whilst, the refractory matter is composed of complex substances like humic acids and fulvic acids which is slowly broken down by bacteria into more readily assimilable compounds (Danovaro et al 2001).

The meiofaunal density in the CIOB is very low (Ingole et al 2005) and no correlation exists between macro- and meiofaunal abundances (Pavithran 2008). Hence, meiofauna being directly consumed by macrofauna as a major food source appears uncommon in CIOB. Further, the dominance of deposit feeders over carnivore macrobenthos means that organic matter is the main food for the macrobenthic community in the CIOB. A similar result was documented by Iken et al (2001) in the Porcupine Abyssal Plain region, showing a dominance of deposit feeders over predators/scavengers.

\subsection{Relationship between macrobenthos and sedimentary environmental parameters}

Organic matter is known to be the first order parameter to control the faunal distribution in the deep sea (Danovaro et al 2001; Kröncke et al 2003). The macrobenthic density tends to show a significant correlation with the sediment organic carbon content (figure 3a) and this pattern is well established for the Indian Ocean (Ingole et al 1992; Pavithran et al 2007). Positive correlation of macrobenthos and sediment protein (figure $3 \mathrm{~b}$ ) and no correlation between macrobenthos and $\mathrm{CHO}$ could be due to the dependence of these organisms on fresh organic matter. The significant positive correlation between surface water chl- $a$ and organic carbon (figure 4) as well as macrobenthos and chl- $a$ (figure 3c), reveals that the euphotic primary production contributes a major fraction to the available organic matter reaching the abyssal depths and hence providing food to the deep-sea macrobenthos in CIOB. Furthermore, macrobenthic abundance did not show any relation with sediment texture, which could be due to the smaller depth differences between the sampling stations.

An inverse relationship of macrobenthos, sediment organic carbon and surface water chl- $a$ with latitude (figure $3 \mathrm{~d}-\mathrm{f}$ ) also advocates the importance of surface productivity and sediment organic matter to the macrobenthos. It indicates that food available for benthos decreases with increasing latitudes and corresponds with the decrease in macrobenthos. In the study area, the influence of landmasses decreases considerably towards the south; hence the surface production is also seen to decrease. Moreover, the CIB region is totally isolated from the mainland and the only source of iron $(\mathrm{Fe})$ is dust from islands or landmasses around the Indian Ocean (Matondkar et al 2005). Iron is generally required for the growth of phytoplankton and it has been shown that in the equatorial Pacific where wind-borne dust is as negligible as the source, adding iron to the surface waters stimulates the growth of phytoplankton (Coale et al 1996). Matondkar et al (2005) reported a low concentration of $\mathrm{Fe}\left(154.74 \mathrm{mg} \mathrm{m}^{-2}\right)$ at around $13.5^{\circ} \mathrm{S}$ and this was found to affect the rate of primary productivity $\left(76.26 \mathrm{mg} \mathrm{C} \mathrm{m}^{-2} \mathrm{~d}^{-1}\right)$ in the euphotic zone of the CIOB. However, at around $10.5^{\circ} \mathrm{S}$, high content of Fe $\left(562.75 \mathrm{mg} \mathrm{m}^{-2}\right)$ was found to enhance the primary productivity $\left(103.4 \mathrm{mg} \mathrm{C} \mathrm{m}^{-2} \mathrm{~d}^{-1}\right)$. This confirms that the surface production decreases with increasing latitude southwards in the CIOB, ultimately responsible for the observed latitudinal variation of macrobenthos. Latitudinal species diversity has been studied by Rex et al (1993), in the S. Atlantic wherein a poleward decrease in diversity of isopods, gastropods and bivalves has been observed. Lambshead et al (2000) reported an increase in nematode diversity towards higher latitudes in N. Atlantic. Similarly, in the S. Atlantic, mollusk showed a significant decrease in diversity towards higher latitudes whereas the crustaceans like isopods did not show any significant pattern (Stuart et al 2003). While discussing the global patterns of benthic standing stock, Rex et al (2006) opined that decline in benthic abundance is related to the distance from productive coastal waters and to the rate and seasonal pattern of nutrient input from overhead production (Falkowski et al 1998; Rex et al 2000).

\subsection{Vertical distribution of macrobenthos}

Generally the macrobenthos are dominant in the top 0-1 cm sediment depth (Witte 2000), however in the present study a peak in density as well as diversity was obtained in the $2-5 \mathrm{~cm}$ sediment depth. This could be due to the surface and subsurface deposit feeders moving to the lower depth from the upper sediment layer probably due to the disturbance caused by the box corer during sampling. This can be further confirmed from the work carried out by Witte (2000), wherein it has been argued that the recovery layer of the organisms need not necessarily represent the layer of main activity of the individual, particularly those with vertical tubes, which may feed and live on/in the 
surface layer but escape into deeper layers when disturbed by the box corer. In the food limited areas, even the surface deposit feeders occupy the lower depths of the sediment layer to compensate for the low food availability (Ingole et al 2005).

It is also known that, some macrobenthos can gather as much food as possible in a short time (possibly during high pulse rate), bury it out of the reach of the small fauna and live on it until the next pulse arrives (Jumars et al 1990; Flach et al 1999). Macrobenthic infaunas, especially deposit feeders, are the major agents of particle mixing, also known as bioturbation. Bioturbation leads to increased oxygenation and mineralization rates in sediments (Aller 1994). Dauwe et al (1998) found that sediments containing intermediate quantity and quality of organic matter displayed a higher diversity of trophic groups and a deeper distribution of infauna and that minimal potential mixing was associated with the highest quality of organic matter. Consequently, bioturbation not only affects the vertical distribution of organic matter along the sediment profiles, but also potentially increases the available food concentration at depths within the sediment (Ingole 2004).

Capitellid polychaetes, which are subsurface deposit feeders, were observed in the upper sediment layer of $2-5 \mathrm{~cm}$ as well as at greater sediment depths $(25-30 \mathrm{~cm})$ (Hayashi 1988; D'Andrea and Lopez 1997). The values of organic carbon, protein and carbohydrate in the present study decreased with increasing sediment depth (figure 7), but the carbohydrate did not show much variation. This could be because carbohydrates might represent the main food source for organisms living in the deeper sediment layers (Dell'Anno' et al 2000). Subsurface deposit feeders (which usually feed beneath the sediment mixing depth) are known to be constrained by lower amounts of available organic matter, but according to the optimal foraging theory, this is partially compensated by a diminished competition for available resources (Jumars and Penry 1989). According to Dell'Anno' et al (2000), subsurface consumers would also be subjected to a different diet regime characterized by a large predominance of carbohydrates and possibly different adaptive mechanisms to optimize the exploitation of this trophic source.

\section{Conclusions}

From the current study it can be concluded that CIOB is mainly dominated by deposit feeding polychaetes and predatory omnivorous nematodes, since the macrobenthic distribution depends on the availability of surface primary production and their abundance is strongly related to sedimentary organic matter. Vertically, the presence of fauna at deeper sediment depths could be due to the transport of organic matter by the bioturbators hence facilitating the distribution of fauna in deeper depths.

\section{Acknowledgements}

The authors acknowledge the Ministry of Earth Sciences, Govt. of India for financial support for the project on Polymetallic Nodule-Environment Impact Assessment of Nodule Mining, under which the current work was carried out. We thank the Director, National Institute of Oceanography, for providing the necessary facilities. The first author would like to thank the CSIR for the fellowship provided for carrying out her Ph.D work. We also would like to thank Dr Jürgen Guerrero Kommritz from the Zoologiscehs Museum Hamburg, Germany, for his help in the identification of tanaids. We are thankful to Dr Rahul Sharma, Project Leader, PMN-EIA, for providing valuable comments on the manuscript. We acknowledge the Plymouth Marine Laboratory and the DARWIN Worldwide Pollution-Monitoring Programme for providing training in nematode identification. This is contribution no. 4608 of NIO (CSIR), Goa.

\section{References}

Aller R C 1994 Bioturbation and remineralization of sedimentary organic matter: Effects of redox oscillation; Chem. Geol. 114 331-345.

Coale K H, Johnson K S, Fitzwater S E and Gordon R M et al 1996 A massive phytoplankton bloom induced by an ecosystem-scale iron fertilization experiment in the equatorial Pacific Ocean; Nature 383 495-501.

Cosson-Sarradin N, Sibuet M and Galeron J 1997 Community structure and spatial heterogeneity of the deepsea macrofauna three contrasted stations in the tropical northeast Atlantic; Deep-Sea Res. 44(2) 247-269.

Cosson-Sarradin N, Sibuet M, Paterson G L J and Vangriesheim A 1998 Polychaete diversity at tropical Atlantic deep-sea sites: Environmental effects; Mar. Ecol. Prog. Ser. 165 173-185.

D'Andrea A F and Lopez G R 1997 Benthic macrofauna in a shallow water carbonate sediment: major bioturbators at the Dry Tortugas; Geo-Mar. Lett. 17 276-282.

Danovaro R, Fabiano M and Della Croce N 1993 Labile organic matter and microbial biomasses in deep-sea sediments (eastern Mediterranean Sea); Deep-Sea Res. 40 953-965.

Danovaro R, Della Croce N, Eleftheriou A, Fabiano M, Papadopoulou N, Smith C and Tselepides A 1995 Meiofauna of the deep Eastern Mediterranean Sea: Distribution and abundance in relation to bacterial biomass, organic matter composition and other environmental factors; Prog. Oceanogr. 36 329-341.

Danovaro R, Dell'Anno A and Fabiano M 2001 Bioavailability of organic matter in the sediments of the Porcupine Abyssal Plain, northeastern Atlantic; Mar. Ecol. Prog. Ser. 220 5-32. 
Dauwe B, Herman P M J and Heip C H R 1998 Community structure and bioturbation potential of macrofauna at four North Sea stations with contrasting food supply; Mar. Ecol. Prog. Ser. 173 67-83.

Dell'Anno A, Fabiano M, Lei M L and Danovaro R 2000 Enzymatically hydrolysed protein and carbohydrate pools in deep-sea sediments: Estimates of the potentially bioavailable fraction and methodological considerations; Mar. Ecol. Prog. Ser. 196 15-23.

El-Wakeel S K and Riley J P 1957 The determination of organic carbon in marine muds; J. Con. Int. Expl. Mer. 22 180-183.

Falkowski P G, Barber R T and Smetacek V 1998 Biogeochemical controls and feedbacks on ocean primary production; Science 281 200-206.

Fauchald K and Jumars P A 1979 The diet of worms: A study of polychaete feeding guilds; Oceanogr. Mar. Biol. Annu. Rev. 17 193-284.

Flach E and Heip C 1996 Vertical distribution of macrozoobenthos within the sediment on the continental slope of the Goban Spur area (NE Atlantic); Mar. Ecol. Prog. Ser. 141 55-66.

Flach E, Vanaverbeke J and Heip C 1999 The meiofauna:macrofauna ratio across the continental slope of the Goban Spur (north-east Atlantic); J. Mar. Biol. Ass. U.K. 79 233-241.

Flach E, Muthumbi A and Heip C 2002 Meiofauna and macrofauna community structure in relation to sediment composition at the Iberian Margin compared to the Goban Spur (NE Atlantic); Prog. Oceanogr. 52 433-457.

Folk R L 1968 Petrology of Sedimentary Rocks (Hemphill Publishing Company, Texas).

Gage J D and Tyler P A 1991 Deep-sea biology: A natural history of organisms at the deep-sea floor (Cambridge University Press: Cambridge).

Gaston G 1987 Benthic polychaeta of the Middle Atlantic Bight: Feeding and distribution; Mar. Ecol. Prog. Ser. 36 251-262.

Glover A G, Smith C R, Paterson G L J, Wilson G D F, Hawkins L and Sheader M 2002 Polychaete species diversity in the central Pacific abyss: Local and regional patterns, and relationships with productivity; Mar. Ecol. Prog. Ser. 240 157-170.

Gutiérrez D, Gallardo V A, Mayor S, Neira C, Vásquez C, Sellanes J, Rivas M, Soto A, Carrasco F and Baltazar M 2002 Effects of dissolved oxygen and fresh organic matter on the bioturbation potential of macrofauna in sublittoral sediments off Central Chile during the 1997/1998 El Niño; Mar. Ecol. Prog. Ser. 202 81-99.

Hayashi I 1988 Vertical distribution of macrobenthic organisms in various sediments of the shelf area in the sea of Japan with special reference to polychaetous annelids; Nippon Suisan Gakk. 54(12) 2071-2078.

Iken K, Brey T, Wand U, Voigt J and Junghans P 2001 Food web structure of the benthic community at the Porcupine Abyssal Plain (NE Atlantic): A stable isotope analysis; Prog. Oceanogr. 50 383-405.

Ingole B S 2004 Bottom dwelling animals-benthos; In: Know your shore (ed.) Untawale A G; World Wildlife Fund, Goa, India.

Ingole B S, Ansari Z A and Parulekar A H 1992 Benthic fauna around Mauritius Island, southwest Indian Ocean; Indian. J. Mar. Sci. 21 268-273.

Ingole B S, Ansari Z A, Rathod V and Rodrigues N 2001 Response of deep-sea macrobenthos to a small scale environmental disturbance; Deep-Sea Res. II 48 3401-3410.

Ingole B S, Pavithran S and Ansari Z A 2005 Restoration of deep-sea macrofauna after simulated benthic disturbance in the Central Indian Basin; Mar. Georesour. Geotechnol. 23(4) 267-288.

Jumars P A and Penry D L 1989 Digestion theory applied to deposit feeding. Ecology of marine deposit-feeders; In: Lecture notes coastal and estuarine studies (eds) Lopez G, Tagon G and Levinton J (New York: Springer-Verlag). Jumars P A, Mayer L M, Deming J W, Baross J A and Wheatcroft R A 1990 Deep-sea deposit-feeding strategies suggested by environmental and feeding constraints; Philos. Trans. R. Soc. A 331 85-101.

Kochert G 1978 Carbohydrate determination by phenolsulfuric acid method. In: Handbook of Phycological Methods; In: Physiological and Biochemical Methods; (eds) Hellebust J A and Craigie J S (Cambridge: Cambridge University Press).

Kröncke I, Türkay M and Fiege D 2003 Macrofauna communities in the eastern Mediterranean deep-sea; Mar. Ecol. 24 193-216.

Lambshead P J D, Tietjen J, Ferrero T and Jensen P 2000 Latitudinal diversity gradients in the deep sea with special reference to North Atlantic nematodes; Mar. Ecol. Prog. Ser. 194 159-167.

Lampitt R S and Antia A N 1997 Particle flux in deep seas: Regional characteristics and temporal variability; DeepSea Res. 44(8) 1377-1403.

Lowry O H, Rosebrough N J, Farr A L and Randall R 1951 Protein measurement with the folin phenol reagent; J. Biol. Chem. 193 265-275.

Matondkar S G P, Nair K K C and Ansari Z A 2005 Biological characteristics of Central Indian Basin waters during the southern summer; Mar. Georesour. Geotechnol. 23 299-314.

Maurer D, Robertson G and Gerlinger T 1994 Comparison of community structure of soft-bottom macrobenthos of the Newport Submarine Canyon, California and the adjoining shelf; Int. Rev. Ges. Hydrobiol. 79 591-603.

Moens T, Verbeeck L and De Maeyer A et al 1999 Selective attraction of marine bacterivorous nematodes to their bacterial food; Mar. Ecol. Prog. Ser. 176 165-178.

Pattan J N, Masuzawa T and Borole D V et al 2005 Biological productivity, terrigenous influence and noncrustal elements supply to the Central Indian Ocean Basin: Paleoceanography during the past $\sim 1 \mathrm{Ma}$; J. Earth Syst. Sci. 114(1) 63-74.

Pavithran S 2008 Deep-sea treasure of macrofaunal communities from the Central Indian Ocean Basin; Ph.D. thesis, Goa University, Goa, India.

Pavithran S, Ingole B, Nanajkar M and Nath B N 2007 Macrofaunal diversity in the Central Indian Ocean Basin; Biodiversity 8(3) 11-16.

Prasad M S 2007 Indian exploration for polymetallic nodules in the Central Indian Ocean; International Seminar on "Minerals and Other Resources Found in Marine Areas beyond the Limits of National Jurisdiction (The "Area"), Manado, North Sulawesi, Indonesia.

Rex M A, Stuart C T, Hessler R R, Allen J A, Sanders H L and Wilson G D F 1993 Global-scale latitudinal patterns of species diversity in the deep-sea benthos; Nature $\mathbf{3 6 5}$ 636-639.

Rex M A, Stuart C T and Coyne G 2000 Latitudinal gradients of species richness in the deep sea benthos of the North Atlantic; Proc. Natl. Acad. Sci. USA 97 4082-4085.

Rex M A, Etter R J and Morris J S et al 2006 Global bathymetric patterns of standing stock and body size in the deep-sea benthos; Mar. Ecol. Prog. Ser. 317 1-8.

Richardson M D and Young D K 1987 Abyssal benthos of the Venezuela Basin, Caribbean Sea: Standing stock considerations; Deep-Sea Res. 34 145-164. 
Riemann F 1983 Biological aspects of deep-sea manganese nodule formation; Oceanol. Acta. 6 303-311.

Santosa M F L, Lanab P C, Silvaa J, Fachelc J G and Pulgatid F H 2009 Effects of non-aqueous fluids cuttings discharge from exploratory drilling activities on the deepsea macrobenthic communities; Deep-Sea Res. 56 32-40.

Satellite Geodesy, Scripps Institute of Oceanography, University of California. (http://topex.ucsd.edu/WWW html/mar_topo.html), cited 21 June 2007.

Sibuet M, Lambert C E, Chesselet R and Laubier L 1989 Density of the major size groups of benthic fauna and trophic input in deep basins of the Atlantic Ocean; J. Mar. Res. 47 851-867.

Stuart C T, Rex M A and Etter R J 2003 Large-scale spatial and temporal patterns of deep-sea benthic species diversity; In: Ecosystems of the Deep Oceans (ed.) Tyler P A; (Amsterdam: Elsevier) 295-311.
Tietjen J H and Lee J J 1977 Feeding behaviour of marine nematodes; In: Ecology of Marine Benthos (ed.) Coull B C; University of South Carolina Press, Columbia.

Vanreusel A, Vincx M, Schram D and Van Gansbeke D 1995 On the vertical distribution of the metazoan meiofauna in shelf break and upper slope habitats of the NE Atlantic; Int. Rev. Gesamten Hydrobiol. 80 313-326.

Wieking G 2002 The macrofauna at the Dogger bank: Food supply in relation to hydroclimate; Ph.D. thesis, University of Oldenburg, Germany.

Wieser W 1953 Die Beziehung zwischen Mundhohlengestalt, Ernahrungsweise und Vorkommen bei freilebenden mannen Nematoden; Ark. Zool. 4 439-484.

Witte U 2000 Vertical distribution of metazoan macrofauna within the sediment at four sites with contrasting food supply in the deep Arabian Sea; Deep-Sea Res. 47 2979-2997. 